\title{
The timeline of two-stage accretionary processes in eastern Central Asian Orogenic Belt: insights from episodic Paleozoic intrusions in central Inner Mongolia, North China
}

\author{
L.L. YUAN ${ }^{1 * 2}$, X.H. ZHANG ${ }^{2}$, Z.L. YANG ${ }^{2}$ \\ ${ }^{1}$ School of Geoscience and Info-Physics, Central South \\ University, Changsha 410083, China (*correspondence: \\ 1lyuan@126.com) \\ ${ }^{2}$ Institute of Geology and Geophysics, Chinese Academy of \\ Sciences, Beijing 100029, China
}

Along the southeastern segment of Central Asian Orogenic belt, the North China-South Mongolia (NCSM) tract had went through a prolonged subduction-accretion course and crustal growth odyssey. However, the affinities of ancient microcontinents involved in orogeneses, the nature of this multi-stage accretionary process, and the delicate procedures concerning plural crustal generations across the realm are controversial. This geochronological and geochemical study documents four distinct periods of Paleozoic plutonism from the Erenhot region of central Inner Mongolia, North China. The geochemical traits of Late Cambrean-Late Ordovician felsic to mafic intrusive sequence indicate derivation from partial melting of altered oceanic crust, juvenile mafic underplates and melt-fertilized mantle wedge underlying a maturing intra-oceanic island arc, which was probably amalgamated to the neighboring terrane mosaic during Early-Middle Devonian. The Late Devonian to Early Carboniferous calc-alkaline intermediate to felsic suites recorded the gradual creation of an arc-back-arc system within the newly-established Andean-type continental margin. The latest Carboniferous high-Mg diorites and A-type granites registered concurrent mantle and crustal melting processes during ridge-trench interactions that possibly promoted the back-arc basin closure. The Early Permian postcollisional gabbro-diorite complex provides the first documentation of an evolved lithospheric mantle domain in the NCSM tract. Therefore, based on our results and available data from contiguous regions, we established a detailed magmatic profile in the NCSM collage that characterized an unique two-stage growth of a protracted retreating accretionary orogen. Harboring juvenile but variable isotopic barcodes, these multiple Paleozoic magmatic episodes also make salient contributions to link tectonic evolution and crust generation in a long-lived active margin. 